\title{
ЕЛЕКТРОПОРАЦІЯ ЯК СПОСІБ ЛІКУВАННЯ ПРОБЛЕМ ШКІРИ
}

\author{
Скринська О. С., магістр \\ Sasha-aevum@ukr.net \\ Антонова-Paфi Ю. В., доцент каф. біобезпеки і здоров'я людини, к.т.н. \\ Antonova-rafi@ukr.net \\ Худецький I. Ю., зав. каф. біобезпеки і здоров'я людини, професор, д.м.н. \\ Igorkhudetskyy@gmail.com \\ Факультет біомедичної інженерії \\ Національний технічний університет України \\ «Київський політехнічний інститут імені Ігоря Сікорського» \\ м. Київ, Україна
}

\begin{abstract}
Реферат - проблеми косметології сьогодні дуже актуальні. Зовнішність дає можливість мати гарне життя. Нажаль, велика кількість людей має проблеми зі шкірою обличчя, які починаються з молоду, і ие тягне за собою матеріальні. Існує широкий вибір способів лікування дефектів шкіри. Існує широкий спектр кремів, для різних типів шкіри і для боротьби з різними проблемами шкіри. Навіть створені спеціальні набори-комплекси по догляду за шкірою обличчя. Також існують різноманітні більш ефективні апаратні методики лікування, такі як ультразвукова чистка, лазерний пілінг, ін'єкційна мезотерапія, електропорація. На сьогоднішній день електропорація використовується в самих різноманітних областях, наприклад, в медиџині для лікування раку, в біотехнології для створення гібридів, в косметології для доставки ліків в клітини. Де б не застосовувався ией метод, він завжди заснований на впливі електромагнітних імпульсів на мембрану клітини для утворення пір необхідних розмірів. Останнім часом метод електропорачї став широко використовуватися в косметології, як метод без ін'єкційної мезотерапї. При електропорації в бімаровій ліпідній мембрані виникає локальна перебудова структури, яка веде до появи оборотних наскрізних водних каналів. Цей метод сприяє швидшому проникненню необхідних речовин (ліків, вітамінів) всередину. Така техніка збільшує проникність клітин в 400 разів. При цьвому проникає близько 90-100\% активних речовин. Цей метод повністю неінвазивний $і$ безболісний. Надає видимий ефект після першої прочедури, і він не потребує часу на відновлення шкіри після процедури, оскільки не викликає ніякого видимого подразнення.Метод проявив свою ефективність у вирішенні безлічі проблем, таких як: вікові зміни шкіри, лікування вугрової висипки, відновлення еластичності і водного балансу шкіри, лікування целюліту.
\end{abstract}

Ключові слова - електропорачія, косметологія, безін'єкційна мезотерапія.

\section{I. Вступ}

Зовнішній вигляд дуже важливий для людей. Ми готові заплатити будь-яку ціну, щоб виглядати красиво. Сьогодні, гарна зовнішність дає нам можливість отримати кращу роботу або вищу посаду, мати хороші стосунки. Таким чином, захворювання шкіри приносять людям не тільки матеріальні проблеми, але й моральні.

Шкіра людини приймає на себе перший удар від забрудненого середовища, хлорованої води, низькоякісної косметики. На жаль, ситуація погіршується через недостатне харчування, недосипання та постійний стрес.

На жаль, за даними закордонних джерел, близько $90 \%$ підлітків страждають від вугрів [1], це не тільки не красива шкіра у віці від 14 до 20 років, а навіть після 20 років, приблизно 40 \% людей продовжують страждати від цієї проблеми.Також можливі наслідки після вугрів, такі як шрами, які не прикрашають обличчя. Від $22 \%$ до $52 \%$ пацієнтів вирушають до лікарень 3 патологічними рубцями [1]. На жаль, це не єдина проблема, після 30 починають з'являтися зморшки.

3 давніх-давен люди намагалися запобігти i подолати ці проблеми масажем, масками. Тоді почали з'являтися різні креми, ін'єкції, ультразвукова чистка обличчя, лазерний пілінг, електропорація та багато інших косметичних рішень.

Сьогодні існує велика кількість різних косметичних засобів: кремів, лосьйонів, гелів для різних типів шкіри, для вирішення різних проблем, різних марок, безлічі різноманітних апаратних процедур.

\section{II. Методи лікування}

При лазерному пілінгу на шкіру наноситься спеціальний крем, після чого проблемні зони обробляються лазером (рис. 1). Кожен пацієнт має власний курс, який залежить від часу впливу і довжини лазерного променя.

Лазерний пілінг обличчя спрямований на боротьбу з нерівномірним рельєфом (шрами, 
постакне), зморшками, віковими плямами, веснянками, розширеними порами, зниженим тургором і тонусом шкіри, млявим кольором. У таблиці 1 ми бачимо, результати при використанні лазерного пілінгу.

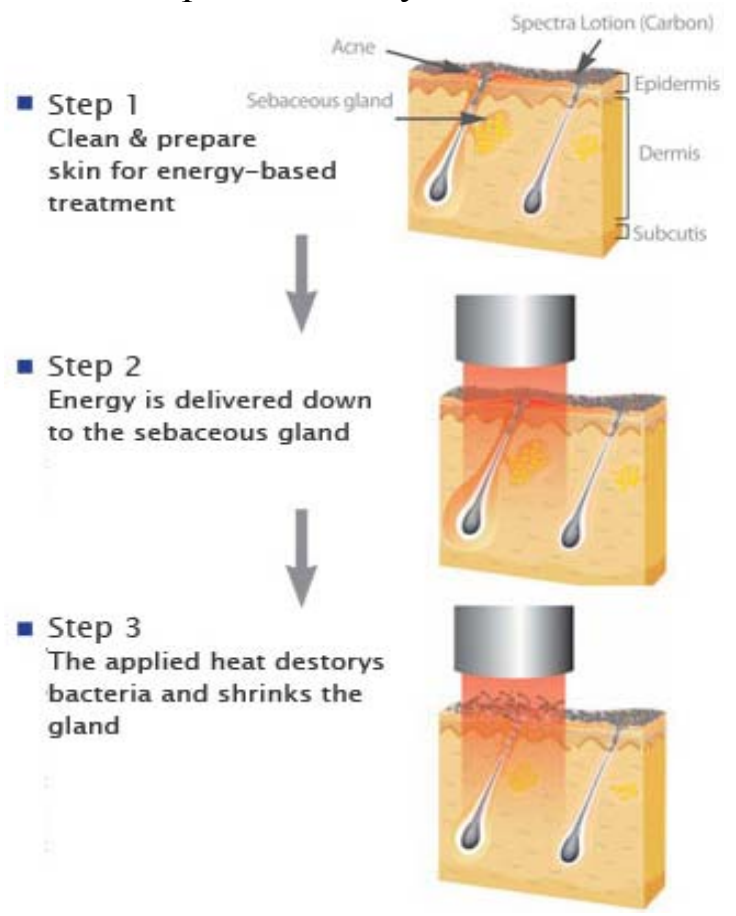

Puc. 1. Лазерний пілінг [2]

Таблиця 1. Відновлення після лазера $[2,3]$

\begin{tabular}{|c|c|c|c|c|}
\hline \multirow{2}{*}{$\begin{array}{c}\text { Проблема, } \\
\text { к-ть пацієнтів }\end{array}$} & \multicolumn{4}{|c|}{ Період лікування } \\
\cline { 2 - 5 } & $\mathbf{1 , 5}$ мic. & $\mathbf{2}$ міс. & $\mathbf{2 , 5}$ міс. & 3 мic. \\
\hline акне, 130 & $66 \%$ & $21 \%$ & $9 \%$ & $4 \%$ \\
\hline омоложення, 86 & $44 \%$ & $31 \%$ & $17 \%$ & $8 \%$ \\
\hline
\end{tabular}

Протипоказання включають будь-які запальні процеси, епілепсію, вагітність, цукровий діабет. Після процедури необхідно почекати поки пройде почервоніння, для цього підбирають індивідуальний косметичний комплекс 3 вітамінами. Процедура може бути повторена не раніше ніж через 7-10 днів.

Ультразвукове очищення включає в себе ефективне та глибоке очищення шкіри та пір (рис. 2) від забруднень, шкірного жиру.

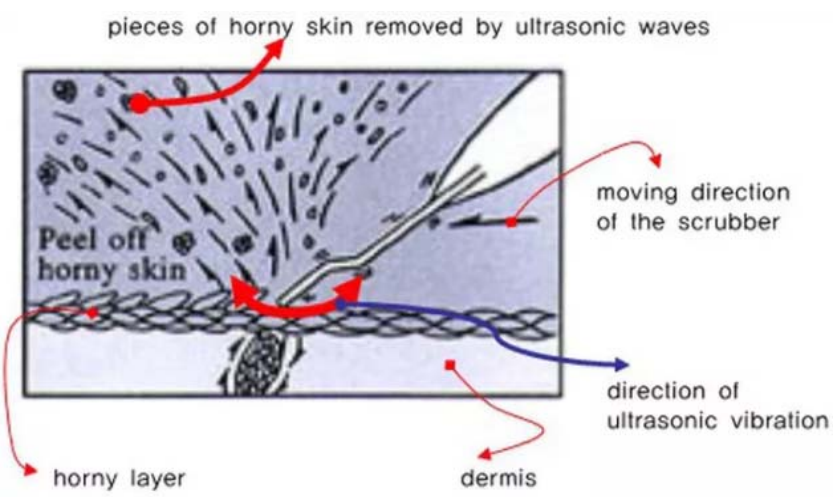

Puc. 2. Ультразвук [7]
Процедура застосовується при пористої шкіри, зменшеному тургорі і тонусу шкіри, наявності комедонів, вугрів (але не в гострому стані), жирній шкіри, комбінованій шкірі, надмірній пітливості, млявому кольорі обличчя. Деякі результати лікування наведено в таблиці 2.

Таблиця 2. Відновлення після ультразвуку [7]

\begin{tabular}{|c|c|c|c|c|}
\hline \multirow{2}{*}{$\begin{array}{c}\text { Проблема, } \\
\text { i к-ть пацієнтів }\end{array}$} & \multicolumn{4}{|c|}{ Період лікування } \\
\cline { 2 - 5 } & $\mathbf{1 , 5}$ мiс. & $\mathbf{2}$ міс. & $\mathbf{2 , 5}$ міс. & 3 мic. \\
\hline акне, 78 & $56 \%$ & $20 \%$ & $12 \%$ & $10 \%$ \\
\hline омоложення, 73 & $48 \%$ & $19 \%$ & $19 \%$ & $14 \%$ \\
\hline
\end{tabular}

Протипоказаннями до ультразвуку є екзема, фурункули, епілепсія, вагітність. Метод безболісний. Наприкінці процедури застосовується спеціальна маска, щоб зменшити почервоніння. Процедура може бути повторена через 7 12 днів.

Фракційний термоліз використовує лазер на проблемній ділянці, створюючи мікротріщини. Процедура супроводжується неприємними відчуттями. Лазерне світло під час процедури подають на шкіру пучком сотень мікропроменів, а не плямою, як у випадку лазерного шліфування. Кожен промінь впливає на мікроскопічну область шкіри, руйнуючі старі клітини в цій ділянці та стимулює формування нових (рис. 3).
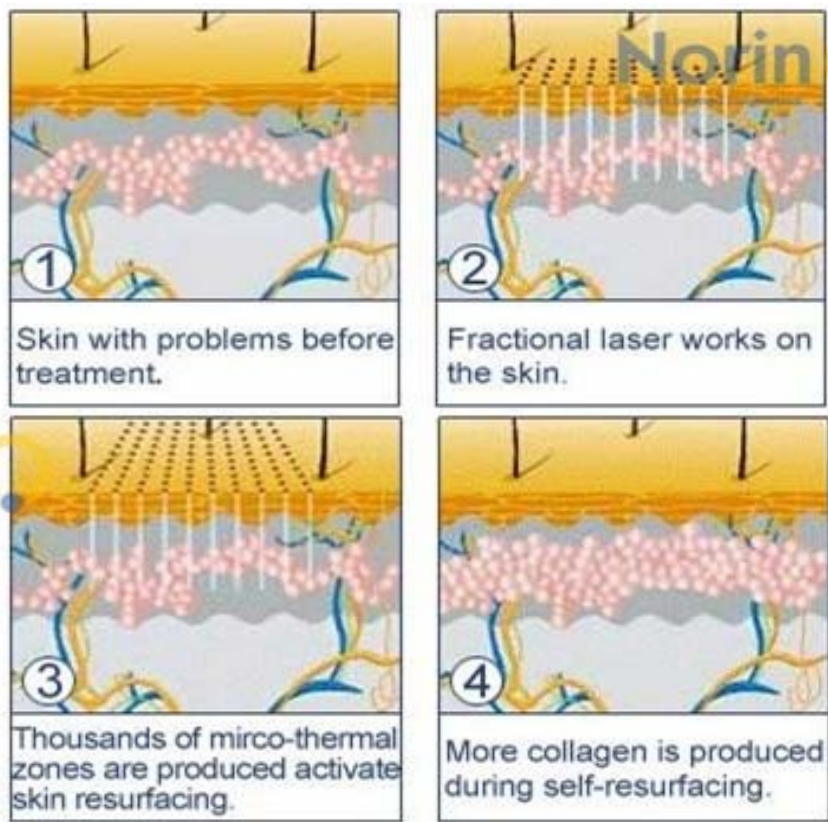

Fractional laser works on the skin.

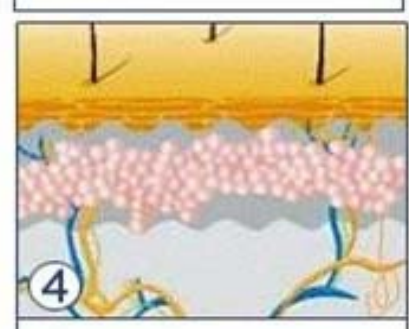

More collagen is produced during self-resurfacing.

Рuc. 3. Фракційний термоліз [5]

В результаті фракційного термолізу зникають шрами, розтяжки, звужуються розширені пори, тон шкіри стає рівним, зникають зморшки. Результати лікування післяфракційного термолізу наведено в таблиці 3. 
Таблиця 3. Відновлення після фракційного термолізу [3, 5]

\begin{tabular}{|c|c|c|c|c|}
\hline \multirow{2}{*}{$\begin{array}{c}\text { Проблема, } \\
\text { i к-ть пацієнтів }\end{array}$} & \multicolumn{4}{|c|}{ Період лікування } \\
\cline { 2 - 5 } & $\mathbf{1 , 5}$ міс. & $\mathbf{2}$ міс. & $\mathbf{2 , 5}$ міс. & 3 міс. \\
\hline акне, 64 & $43 \%$ & $35 \%$ & $13 \%$ & $9 \%$ \\
\hline омоложення, 54 & $41 \%$ & $33 \%$ & $16 \%$ & $10 \%$ \\
\hline
\end{tabular}

Протипоказаннями є псоріаз, запалення, діабет, епілепсія, вагітність. В кінці термолізу слід дотримуватися рекомендацій спеціаліста щодо періоду відновлення шкіри обличчя (4-5 днів). У середньому вам потрібно від 3 до 5 сеансів, щоб результат тривав близько 3 років.

При ін'єкційній мезотерапії обличчя використовується дуже тонка голка (діаметр 0,3 мм), яка вводиться внутрішньошкірно, поверхнево, до глибини 1-2 мм. У той же час шкіра насичується різними лікарськими речовинами, вітамінами, мікроелементами або гомеопатичними засобами. Голки використовуються для створення багатьох мікроскопічних каналів вглиб шкіри дерми, які стимулюють клітини виробляти новий колаген. Ці канали також покращують проникнення кремів, вітамінів А та С приблизно в 1000 разів. Вітаміни А та С стимулюють відновлення шкіри, тим самим, шкіра виглядає свіжою і молодшою. Для того, щоб мезотерапія дала відчутний результат, в середньому вам потрібно пройти 10 процедур. Період лікування триває від двох до шести тижнів. Їх головним недоліком $є$ неприємні відчуття зумовлені болем.

Показаннями для застосування мезотерапії є: зморшки, в'ялість шкіри, кола під очима, пористість шкіри, жирна або суха шкіра, вугрі (поза загостренням), шрами, пігментні плями. Основними протипоказаннями є запалення шкіри, вагітність, епілепсія, гемофілія.

Таблиця 4. Відновлення після мезотерапії [6]

\begin{tabular}{|c|c|c|c|c|}
\hline \multirow{2}{*}{$\begin{array}{c}\text { Проблема, } \\
\text { i к-ть паціснтів }\end{array}$} & \multicolumn{4}{|c|}{ Період лікування } \\
\cline { 2 - 5 } & $\mathbf{1 , 5}$ мic. & $\mathbf{2}$ міс. & $\mathbf{2 , 5}$ мic. & 3 мic. \\
\hline акне, 60 & $35 \%$ & $33 \%$ & $27 \%$ & $5 \%$ \\
\hline омоложення, 72 & $37 \%$ & $31 \%$ & $19 \%$ & $13 \%$ \\
\hline
\end{tabular}

Реконструкція колагену в нормі займає принаймні 90 днів, тому видимі ефекти від цього лікування можуть повністю проявитисячерез три місяці після процедури.

В даний час особлива увага приділяється методу електропорації, що базується на впливі електромагнітних імпульсів на клітинну мембрану з формуванням пір необхідних розмірів. Це тимчасове явище дестабілізації клітинної мембрани під дією імпульсу електричного поля на ньому (рис. 4), що призводить до збільшення електропровідності клітинної мембрани.
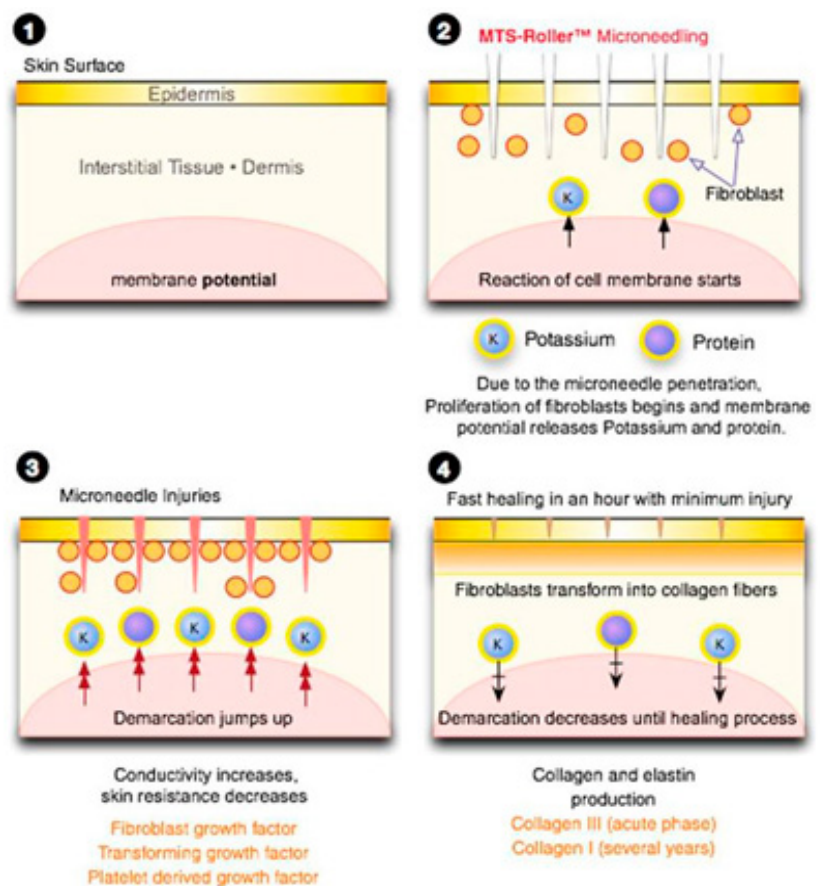

Puc. 4. Мікроін'єкційна мезотерапія [6]

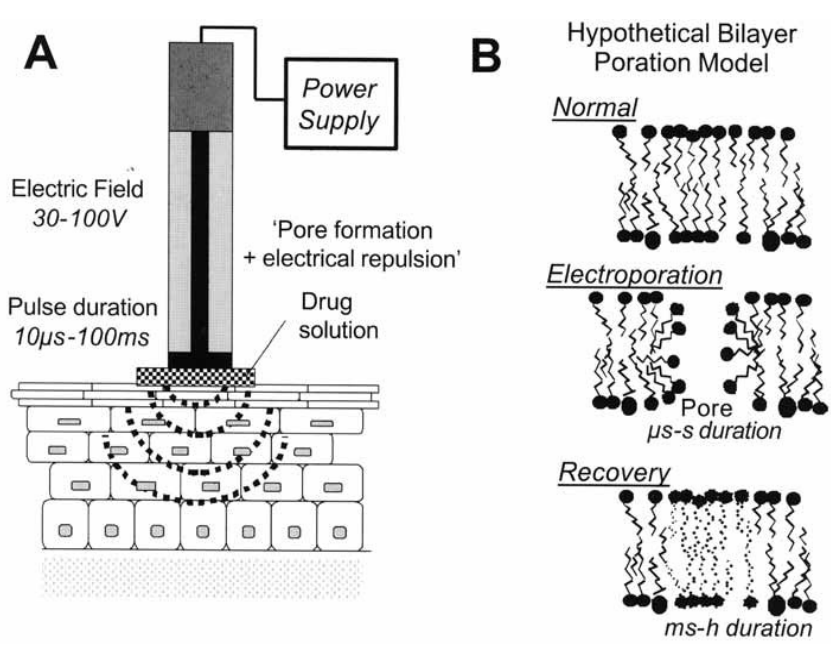

Puc. 5 - Електропорація [4]

Під час дестабілізації мембрана стає надзвичайно проникною навіть для великих молекул. У біліпідній мембрані відбувається перебудова ліпідів, що призводить до появи оборотних водних каналів.

За допомогою електропорації необхідні речовини швидше проникають у клітини. Таким чином, близько 90-100 \% речовин потрапляють всередину.

Електропорація показала свою ефективність у вирішенні найрізноманітніших проблем, таких як: зміни віку шкіри, лікування вугрів, відновлення еластичності та водяного балансу шкіри, лікування целюліту. 
Таблиця 5. Відновлення після електропорації [4]

\begin{tabular}{|c|c|c|c|c|}
\hline \multirow{2}{*}{$\begin{array}{c}\text { Проблема, } \\
\text { i к-ть пацієнтів }\end{array}$} & \multicolumn{4}{|c|}{ Період лікування } \\
\cline { 2 - 5 } & $\mathbf{1 , 5}$ мic. & 2 мic. & $\mathbf{2 , 5}$ мic. & 3 мic. \\
\hline акне, 80 & $66 \%$ & $29 \%$ & $4 \%$ & $1 \%$ \\
\hline омоложення, 66 & $51 \%$ & $31 \%$ & $11 \%$ & $7 \%$ \\
\hline
\end{tabular}

Електропоратори також можливо використовувати вдома. Залежно від стану шкіри, це займає від 4 до 10 сеансів, тривалість одного сеансу варіюється від 20 до 40 хвилин. Процедуру можна повторити через 10-14 днів. Процедура абсолютно безболісна і не потребує періоду відновлення. Основними протипоказаннями $є$ епілепсія та вагітність. Цей пристрій може зробити нашу шкіру красивою на довгий час. Таким чином, електропорація $\epsilon$ одним із найкращих способів повернення шкіри в норму.

В даний час метод незворотної електропорації знайшов широке застосування в онкології. На відміну від застосування цієї техніки в косметології, коли ефект електричного струму $\epsilon$ однорідним і короткочасним, в онкології короткі імпульси багато разів діють в одному місці скупчення клітин. Дія електричного імпульсу під час роботи призводить до поляризації мембрани. Білкові молекули мембрани розпадаються, при утворенні мікропір, які поступово розширюються, об'єднуються з сусідніми, а потім клітина повністю руйнується.

У таблиці 5 показано відсоток людей, з відновленням стану шкіри в період перших 1,5 місяців залежно від виду лікування, використовуючи дані деяких косметичних салонів.

Таблиця 5. Відновлення після 1,5 місяців

\begin{tabular}{|c|c|c|c|c|c|}
\hline Лікування & 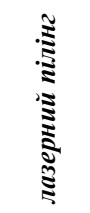 & 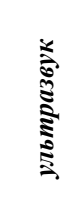 & 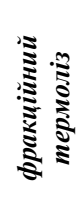 & 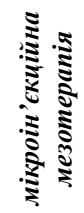 & 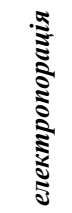 \\
\hline акне & $66 \%$ & $56 \%$ & $43 \%$ & $35 \%$ & $56 \%$ \\
\hline омоложення & $44 \%$ & $48 \%$ & $41 \%$ & $37 \%$ & $51 \%$ \\
\hline
\end{tabular}

На сьогодні одна процедура лазерного пілінгу складає 70 євро, ультразвукова чистка 16 євро, електропорація - 12 євро [2, 4, 7].

Таблиця 6. Кількість процедур за 1,5 місяці і витрати в свро

\begin{tabular}{|c|c|c|c|}
\hline лікування & $\begin{array}{c}\text { лазерний } \\
\text { пілінг }\end{array}$ & ультразвук & електропорація \\
\hline к-ть процедур & 4 & 4 & 4 \\
\hline вартість & 280 & 64 & 48 \\
\hline
\end{tabular}

Таким чином, на підставі даних 3 таблиць 5 та 6, а також попередньої інформації про різні способи лікування, найбільш ефективне лікування відбувається 3 використанням електропорації. Цей метод популярний також через відсутність болю. Друге місце в ефективному лікуванні шкірних проблем займає лазерний пілінг. Це дуже ефективно, але це викликає певний дискомфорт. Ультразвуковий - безболісний спосіб лікування, але лікування потребує більше часу. Фракційний термоліз все ще є одним 3 хороших методів лікування, але його рідко використовують через біль під час процедури та тривалий періоду відновлення.

\section{III. Висновок}

Електропорація $є$ найкращим новим способом швидкого відновлення без болю. Оскільки метод спрямований на відновлення, дану нам природою, красою. Клітини просто втрачають необхідні елементи, тому електропорація повертається до них. Метод електропорації дозволяє поліпшити тургор шкіри і колір обличчя, видаляти розтяжки і шрами, позбутися від вугрів, підвищити еластичність шкіри. Це лікування швидко і менше протипоказань.

\section{ПЕРЕЛІК ПОСИЛАНЬ}

[1] Горячкина М. В. Комбинированная терапия акне у женщин: поиск оптимальных решений / М. В. Горячкина, Т. А. Белоусова. // Вестник дерматологии и венерологии. 2014. - №2. - C. 90-95.

[2] ЗОРИЛЭ В. В. Аппаратная косметология / В. В. ЗОРИЛЭ. // Косметика и медицина. - 2007. - №1. - С. 8-13.

[3] Путинцева П. А. Способы восстановления эластичности кожи и их эффективность (на примере некоторых современных методов) / П. А. Путинцева, Е. Д. Конышева, Д. Е. Мильчаков. // Международный научно-исследовательский журнал. - 2015. - №3. - С. 97-99.

[4] Alexiades-Armenakas M. The spectrum of laser skin resurfacing: Nonablative, fractional, and ablative laser resurfacing / M. Alexiades-Armenakas, J. Dover, K. Arndt. // J Am Acad Dermatol. - 2008. - №58. - p. 719-737.

[5] Neumann E. Electroporation and electrofusion in cell biology E. Neumann, A. Sowers, C. Jordan. - New York, 1989. 435 p. - (Springer science). - (ISBN 978-1-4899-2530-5).

[6] Jaafar A. Apparatus and method for reducing subcutaneous fat deposits, virtual face lift and body sculpturing by electroporation // Patent No.: US 6,892,099 B2 - 2005.

[7] Zhang Y. Absorption of human skin and its detecting platform in the process of laser cosmetology / Y. Zhang, L. // Biomedical Photonicsand Optoelectronic Imaging. - 2000. №42. - C. 23-31. 


\title{
UDC 615.84
}

\section{ELECTROPORATION AS A WAY TO TREAT PROBLEM SKIN}

\author{
Skrinska A., magistr \\ Sasha-aevum@ukr.net \\ Antonova-Rafi Y., Associate Professor Department of Biosecurity and Health, \\ candidate of technical sciences \\ Antonova-rafi@ukr.net \\ Khudetsky I., Head of the Department of Biosecurity and Health, \\ professor, doctor of medical sciences \\ Igorkhudetskyy@gmail.com \\ Faculty of Biomedical Engineering \\ National Technical University of Ukraine \\ "Igor Sikorsky Kyiv Polytechnic Institute" \\ Kyiv, Ukraine
}

\begin{abstract}
Appearance makes it possible to have a good life. Unfortunately, a large number of people have skin problems that begin from a young age, and this entails not only psyhologycal, but also material problems. There is a wide choice of ways to treat skin defects. There is a wide range of creams for different skin types and for dealing with various skin problems. Even special sets-complexes for skin care of the face are created. There are also various more effective hardware treatment techniques, such as ultrasonic cleaning, laser peeling, injection mesotherapy, electroporation. To date, electroporation is used in a variety of areas, for example, in medicine for the treatment of cancer, in biotechnology to create hybrids, in cosmetology for the delivery of drugs to the cells. Wherever this method is used, it is always based on the effect of electromagnetic pulses on the cell membrane to form pores of the required dimensions. Recently, the electroporation method has become widely used in cosmetology, as a method of non-injection mesotherapy. During electroporation in the bilayer lipid membrane, a local restructuring of the structure occurs, leading to the appearance of reversible through water channels. This method promotes faster penetration of necessary substances (drugs, vitamins) inside. This technique increases cell permeability by 400 times. In this case, about $90-100 \%$ of the active substances penetrate. This method is completely non-invasive and painless. Provides a visible effect after the first procedure, and it does not take time to restore the skin after the procedure, since it does not cause any noticeable irritation. The method has shown its effectiveness in solving a variety of problems, such as: age-related skin changes, acne treatment, and restoration of elasticity and water balance of the skin, cellulite treatment.
\end{abstract}

Keywords - electroporation, cosmetology, noninjection mesotherapy. 


\title{
ЭЛЕКТРОПОРАЦИЯ КАК СПОСОБ ЛЕЧЕНИЯ ПРОБЛЕМНОЙ КОЖИ
}

\author{
Скринская А. С., магистр \\ Sasha-aevum@ukr.net \\ Антонова-Рафи Ю. В., доцент каф.биобезопасности и здоровья человека к.т.н. \\ Antonova-rafi@ukr.net \\ Худецкий И. Ю., зав. каф.биобезопасности и здоровья человека, \\ профессор, д.м.н. \\ Igorkhudetskyy@gmail.com \\ Факультет биомедицинской инженерии \\ Национальный технический университет \\ «Киевский политехнический институт имени Игоря Сикорского» \\ г. Киев, Украина
}

\begin{abstract}
Реферат - проблемы косметологии сегодня очень актуальны. Внешность дает возможность иметь хорошую жизнь. К сожалению, большое количество людей имеет проблемы с кожей лица, которые начинаются с молодой, и это влечет за собой материальные.Существует широкий выбор способов лечения дефектов кожи. Существует широкий спектр кремов для разных типов кожи и для борьбы с различными проблемами кожи. Даже созданы специальные наборы-комплексы по уходу за кожей лица. Также существуют различные более эффективные аппаратные методики лечения, такие как ультразвуковая чистка, лазерный пилинг, инъекиионная мезотерапия, электропорация. На сегодняшний день электропорация используется в самых различный областях, например, в медицине для лечения рака, в биотехнологии для создания гибридов, в косметологии для доставки лекарств в клетки. Где-бы не применялся этот метод, он всегда основан на воздействии электромагнитных импульсов на мембрану клетки для образования пор необходимых размеров.В последнее время метод электропорации стал широко использоваться в косметологии, как метод безинъекционной мезотерапии. При электропорации в бислойной липидной мембране возникает локальная перестройка структуры, приводящая к появлению обратимых сквозных водных каналов. Этот метод способствует более быстрому проникновению необходимых веществ (лекарств, витаминов) внутрь. Такая техника увеличивает проницаемость клеток в 400 раз. При этом проникает около 90-100\% активных веществ. Этот метод полностью неинвазивный и безболезненный. Предоставляет видимый эффект после первой процедуры, и он не требует времени на восстановление кожи после процедуры, так как не вызывает никакого заметно раздражение. Метод проявил свою эффективность в решении множества проблем, таких как: возрастные изменения кожи, лечение угревой сыпи, восстановление эластичности и водного баланса кожи, лечение целлюлита.
\end{abstract}

Ключевые слова - электропорация, косметология, безинъекционная мезотерапия. 